Хитра О. В., к.е.н., доцент

Хмельнищький університет управління та права імені Леоніда Юзькова м. Хмельницький, Украӥна

DOI: https://doi.org/10.30525/978-9934-26-080-3-10

\title{
ЕКОНОМІКА ВРАЖЕНЬ ЯК НОВІТНЕ СЕРЕДОВИЩЕ РОЗВИТКУ ТУРИСТИЧНОГО БІЗНЕСУ
}

Сучасним трендом економічного розвитку є перехід до нового етапу суспільних відносин, в якому пріоритети для споживачів полягають не стільки у товарах та послугах, скільки в отримуваних від них враженнях [1, с. 3].

В умовах переорієнтації концепції туристичного споживання, швидкої насиченості потреб, розвитку новітніх технологій ведення туристичного бізнесу споживач часто поводиться ірраціонально, керуючись не співвідношенням «ціна - якість», а кількістю позитивних емоцій на одиницю товару [2, с. 25]. При цьому змінюється характер споживчої орієнтації - 3 зовнішньої (споживання утилітарних товарів і послуг) на внутрішню (отримання емоційної насолоди, відчуттів, вражень) [3, с. 15]. Відтак, туристичне враження стає ключовим критерієм якості туристичного продукту [4, с. 25]. Відповідно, здатність компанії породжувати в людині бажані враження визначатиме іiі успіх на ринку [5, с. 203]. Суттєвим чинником стає креативність суб'єктів туристичної діяльності, яка знаходить відображення у споживчих психологічних установках щодо придбання туристичного продукту [4, с. 28]. Управління туристичним продуктом починає базуватися на концепції управління враженнями клієнта, що охоплює як функціональність продукту, так і додаткові цінності нематеріального характеру [6, с. 34].

Економіка вражень - це підхід до виробництва та просування товару або послуги, заснований не на задоволенні конкретної потреби, а на створенні позитивного враження як від виробництва та просування, так і від одержання товару або послуги, 
а також від пов'язаних 3 цим відчуттів [3, с. 14; 7, с. 41]. Ії̈ невід'ємними рисами є висока чутливість до потреб, інтересів, переживань та емоцій споживачів, орієнтація на унікальність товарної пропозиції, безпосередній зв'язок 3 інформаційнокультурним, комунікативним середовищем життєдіяльності людини, поєднання проявів емоційності та раціональності у поведінці суб'єктів ринкового обміну. Окремо слід вказати на багатоаспектність у прийнятті рішень, що пов'язана 3 необхідністю урахування економічних, соціальних, культурних, когнітивних, психологічних, інформаційних та інших чинників людської поведінки.

Враження - це якісні показники розвитку підприємства, якості його товарів та послуг та діяльності кожного співробітника [8, с. 89]. Водночас, споживач розглядається як співвиробник послуги і творець персоніфікованого досвіду. Під «створенням враження» розуміється емоційна праця із залучення до спільної дії споживача у процесі задоволення потреби для отримання додаткової споживчої цінності, формування враження та позитивного ставлення, що базується на персональній інтеракції та вимагає вираження відповідних емоцій у відповідному організаційному контексті [5, с. 205].

Як зазначають Б.Дж. Пайн і Дж.Х. Гілмор [9], враження є особистісними й торкаються людини на емоційному, фізичному, інтелектуальному рівнях. На відміну від товарів і послуг, враження - це особисте відчуття або переживання, яке запам'ятовується, проявляється згодом і зберігається в пам'яті. Розрізняють чотири основних види вражень: розваги, навчання, втеча від реальності, естетика. Враження не несе прямої економічної користі, його не можна негайно «спожити». При споживанні враження накопичуються i формується «база вражень» людини; окремі враження можуть згодом або стиратися 3 пам'яті, або під впливом різних обставин актуалізуватися [3, с. 15].

Діяльність в умовах економіки вражень потребує нових маркетингових інструментів. Сервісно-домінантна логіка передбачає, що підприємство і клієнт у процесі спільного створення 
цінностей взаємодіють в інтерактивному режимі, а вартість товару або послуги залежить від сприйняття контекстного досвіду, вкладеного в клієнтоорієнтований сервіс [10, с. 80]. Маркетинг вражень забезпечує виникнення у клієнтів яскравих вражень (як результат маркетингових комунікацій), створення у них комплексу позитивних емоцій (споживчої цінності) та формування прихильності до бренду [11, с. 98]. Повне «занурення» споживача у світ продукту (торгової марки, бренду) гарантує компанії отримання комерційних вигод [12, с. 44] (час перебування туристів у країні буде ефективно заповнений, що сприятиме збільшенню тривалості подорожі, витрачанню більшої суми коштів та наявності позитивних відгуків).

Для ефективного виробництва «споживчих вражень» слід діяти за принципом масової персоналізації, що визначається як комунікація 3 індивідуальними i мережевими споживачами, створена на базі персональної інформації споживачів [5, с. 206]. У масовій персоналізації комунікацій діють принципи «залучення учасників» у формування мережевого споживчого враження, «спеціалізації та диверсифікації життєвих цінностей», «інтеграції враження і дезінтеграції звернення», «локалізації споживання», «асиметричної інформації», «вузлів комунікації», «віртуальної реальності» [13, с. 234-235].

Розглядаючи враження як самостійний дискретний об'єкт 3 власними характеристиками та процесом розвитку в системі поведінки споживачів, можна стверджувати про синергетичну природу його еволюції. Зокрема, враженням властива дуалістична природа формування на основі матеріальних i нематеріальних чинників, раціональних і суб'єктивних мотивів; загальне враження не є простою сумою вражень від окремих елементів товарної пропозиції; так само колективне враження не можна вважати сукупністю індивідуальних вражень; вплив враження на подальшу поведінку споживачів $є$ лише частково детермінованим. «Мережеве споживче враження»- це підсумковий стан i поведінкова реакція споживача, сформовані у сукупності спільних дій 3 матеріального споживання та 
емоційного переживання під час задоволення потреби, що володіють синергетичною цінністю та визначають ставлення до продукту [5, с. 206]. Виступаючи своєрідною «точкою біфуркації», колективне споживче враження може суттєво поліпшити імідж підприємства чи, навпаки, під впливом ледь помітних флуктуацій обумовити несподіване зниження інтересу до туристичного бренду.

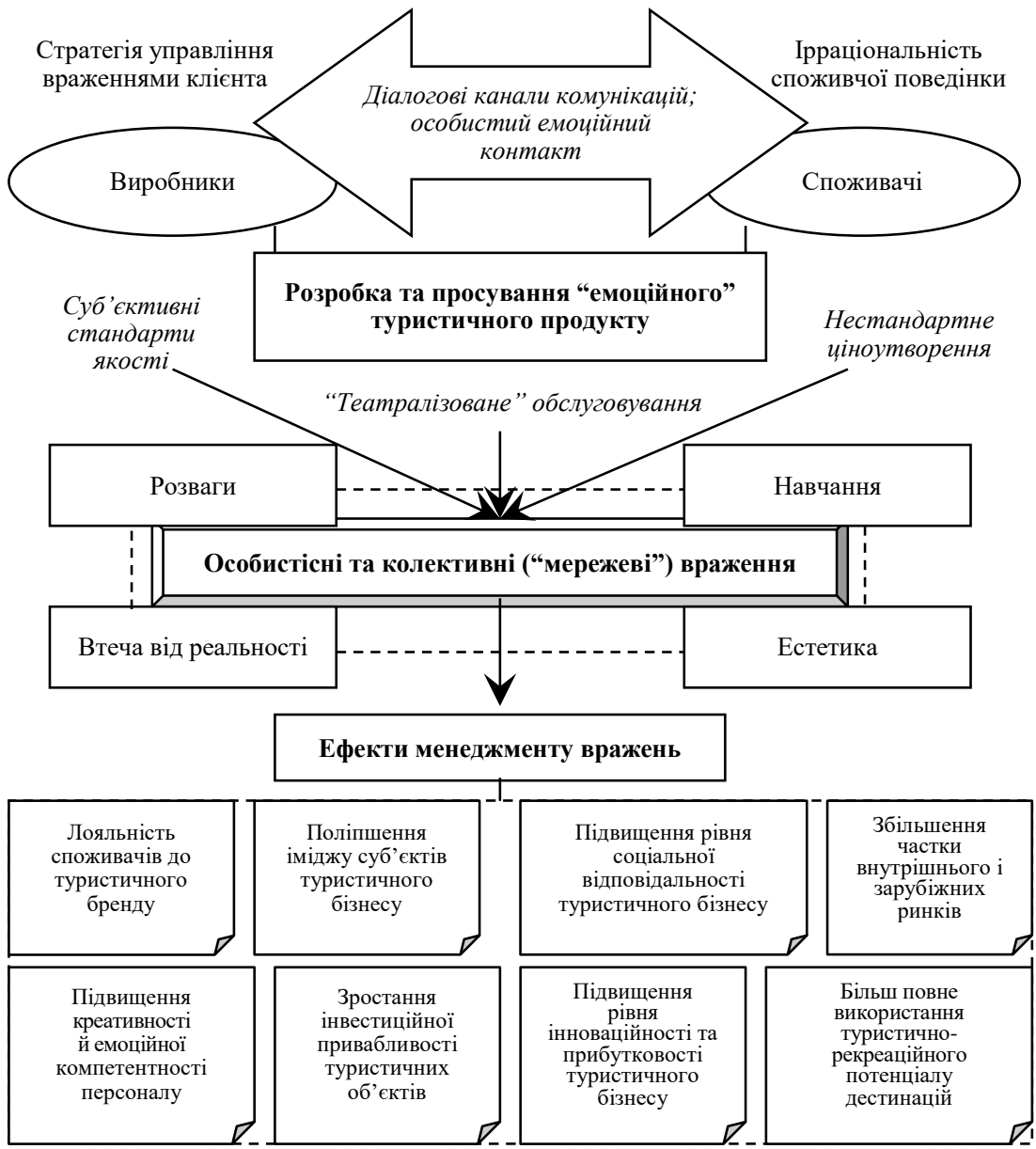

Рис. 1. Особливості функціонування туристичного бізнесу в умовах економіки вражень 
В умовах економіки вражень виникає закономірна потреба формування на туристичних підприємствах системи менеджменту вражень (рис. 1), що означає цілеспрямований управлінський вплив на поведінку споживачів за результатами вивчення їх інтересів, установок, бажань і прагнень з метою забезпечення стійкої емоційної прихильності до компанії та їі продукту.

До специфічних прийомів менеджменту вражень можна віднести інструментарій емоційного маркетингу, клієнтоорієнтованого сервісу, туристичного брендингу, а також тотального менеджменту якості. Завдяки налагодженню персоналізованих, діалогових каналів комунікацій та встановленню особистого емоційного контакту з кожним клієнтом досягається гармонійне узгодження інтересів виробників і споживачів туристичного продукту, які сумісно створюють особливу споживчу цінність.

\section{Література:}

1. Дишкантюк О.В. Економіка вражень - сучасний етап розвитку суспільного виробництва. Економіка харчової промисловості. 2016. Т. 8. Вип. 4. C. 3-9.

2. Боярська М.О. Сутність та визначення економіки вражень на сучасному етапі розвитку економіки України. Молодий вчений. 2016. № 4. С. 25-27.

3. Бойко В.А., Гудзенко О.З. Від споживання послуг до індустрії вражень: концептуальні зміни потреб сучасного споживача. Габітус. 2019. Вип. 10. C. 13-18.

4. Печенюк А.П. Методичні аспекти управління враженнями у сільському туризмі. Вчені записки Таврійського національного університету імені В.I. Вернадського. Серія “Економіка і управління". 2019. Т. 30 (69). № 5(2). C. 25-30.

5. Яроміч С.А., Лахтіонова Т.М., Попель О.О. Інноваційні аспекти маркетингу вражень у сфері туристичних послуг. Інфраструктура ринку. Вип. 21. 2018. С. 203-207. URL: http://www.market-infr.od.ua/journals/2018/ 21_2018_ukr/36.pdf (дата звернення: 13.05.2021).

6. Петриченко П.А. Современные модели управления впечатлениями клиентов. Науковий вісник Херсонського державного університету. 2014. Вип. 6 (2). С. 31-35.

7. Кривобок К.В. Стратегія адаптивних управлінських рішень в умовах економіки вражень. Сучасні проблеми управління підприємствами: теорія та практика : матеріали міжнар. наук.-практ. конф. (Харків - Торунь, 3-4 березня 2020 р.). Харків, 2020. С. 40-42. 
8. Балдинюк А.Г. Менеджмент вражень як стратегічний напрямок розвитку організації та іiі бренду. Науковий вісник Херсонського державного університету. 2014. Вип. 6(2). С. 88-90.

9. Пайн Б.Дж., Гилмор Дж.Х. Экономика впечатлений. Работа - это театр, а каждый бизнес - сцена. Москва : Вильямс, 2005. 304 с.

10. Петриченко П. Клієнтоорієнтований підхід у діяльності підприємств індустрії гостинності. Економіст. 2014. № 1. С. 79-82.

11. Зайцева О.І., Фурсов А.М. Маркетинг вражень як інструмент реалізації клієнтоорієнтованого підходу в діяльності готельних підприємств. Вісник Хмельницького національного університету. Серія "Економічні науки". 2019. № 4. T. 1. C. 95-99.

12. Кривешко О.В. Особливості процесу застосування маркетингу вражень на підприємствах. Інтернаука. Серія “Економічна науки”. 2020. № 2(34). C. 42-49.

13. Петриченко П.А. Управління емоціями та враженнями клієнтів. Вісник соціально-економічних досліджень. 2014. Вип. 2. С. 232-238. 